\title{
The Effects of Valproic Acid on Sciatic Nerve of Fetal Rats and Protective Effects of Folic Acid and Vitamin E
}

\author{
Efectos del Ácido Valproico sobre el Nervio Ciático de Fetos de Ratas \\ y Efectos de Protección del Ácido Fólico y Vitamina $E$ \\ "Mehmet Ufuk Aluclu; ${ }^{* *}$ Mehmet Cudi Tuncer; ${ }^{* * *}$ Aslan Guzel; ${ }^{* * * *}$ Mustafa Arif Aluclu $\&{ }^{* * * * *}$ Murat Akkus
}

ALUCLU, M. U.; TUNCER, M. C.; GUZEL, A.; ALUCLU, M.A. \& AKKUS, M. The effects of valproic acid on sciatic nerve of fetal rats and protective effects of folic acid and vitamin E. Int. J. Morphol., 27(2):285-294, 2009.

SUMMARY: We aimed to investigate the potential harmful effects of maternal valproic acid (VPA) on fetal sciatic nerve, and the protective effects of vitamin E (Vit E) and folic acid (FA) on fetal rats. Valproic acid (400mg/kg), folic acid (400mg/kg) and vitamin E (250 $\mathrm{mg} / \mathrm{kg}$ ) were administered to rats on each of gestation days 8-10. All fetuses were collected on gestation day 20. With thin sections of biopsies, sciatic nerve of fetuses were stained with uranyl acetat and were examined under transmission electron microscope. The fetuses (n:36) were divided into five groups: control, vpa, vpa+fa, vpa+vit e and vpa+fa+vit e groups. In each group; drug procedure, surgical procedure and histological methods were performed. Later, weights and lengths of fetuses in each group were compared and analyzed by One-Way Anova test. Administration of single doses of valproic acid ( $400 \mathrm{mg} / \mathrm{kg}$ ) resulted in weight and length loss between control and vpa group. However, length and weight differences between the other groups were not significant. The histopathological findings of control group was normal. In vpa group, it showed extensive degenerative changes especially in myelin coat. In addition, most prominent finding in this group was condensation of collagen fibers in extensively demyelinated samples, while moderately effected areas were relatively normal. Both vpa+fa and vpa+ vit e groups exhibited similar ultrastructural changes, reflecting minimal to moderate degenerative changes. In vpa+fa+vit e group had almost the normal structure. Administration of single doses of valproic acid (400 $\mathrm{mg} / \mathrm{kg})$ resulted in a deteriorative effect on sciatic nerve at ultrastructural level. Administration of FA and Vit E had a protective effect to prevent the degenerative changes to a certain degree. Combination of FA and Vit E together following VPA administration had a more potent protective effect. The objective of the present study is to analyze histopathologic changes which may occur in a high risk experimental model after the administration of valproic acid. In addition, protective roles of the administration of folic acid and vitamin $\mathrm{E}$ are assessed.

KEY WORDS: Valproic acid; Sciatic nerve; Folic acid; Vitamin E; Rat.

\section{INTRODUCTION}

Valproic acid (VPA) is an antiepileptic drug and has been widely used for clinical purposes since 1978. It binds to plasma proteins at a rate of 91-95\%. Dickinson et al. (1979) have reported that VPA elimination rate for circulation in rats depends on dosage quantity. Teratogenic effects of antiepileptic drugs have been known since 1964; however, their effects on perinatal mortality are low (Biernacki et al., 2000; Nau et al., 1991). Increase in perinatal mortality of epileptic women's infants may be due to multi-factorial reasons. In addition, some reports claim that there is no relation between usage of antiepileptic drug during pregnancy and spontaneous abortion (Annegers et al., 1988).
It is known that VPA can pass through placenta, and lead to congenital anomalies. Therefore, it has been included into teratogenic drugs following retrospective and prospective studies on humans (Ceylan et al., 2001; Lammer et al., 1987; Nau et al.).

The anticonvulsant drug valproic acid is suspected of being a developmental toxicant in humans, inducing primarily neural tube defects. The mechanism for this effect is unknown, but it has been suggested that the drug may act via a deficiency of the vitamin folic acid (Hansen \& Grafton, 1991) The effect of administration of folic acid, vitamin B6

\footnotetext{
Department of Neurology, Faculty of Medicine, University of Dicle, Diyarbakır, Turkey.

** Department of Anatomy, Faculty of Medicine, University of Dicle, Diyarbakır, Turkey

*** Department of Neurosurgery, Faculty of Medicine, University of Dicle, Diyarbakır, Turkey.

***** Department of Anatomy, Faculty of Medicine, University of I nönü, Malatya, Turkey.

${ }^{* * * * * *}$ Department of Histology and Embryology, Faculty of Medicine, University of Dicle, Diyarbakır, Turkey.
} 
+ vitamin B12, and their combination in valproic acid-induced teratogenesis was studied in mice. To that end, VPA $(500 \mathrm{mg} /$ $\mathrm{kg}$, sc) was injected on day 8 of gestation and the vitamins (two dose levels) were injected $1 \mathrm{hr}$ before, immediately before, and $1 \mathrm{hr}$ after VPA administration. Folic acid significantly reduced VPA-induced resorptions (21-24\%). On the other hand, vitamin B6 + vitamin B12 significantly reduced VPA-induced exencephaly (23\%), spina bifida occulta (80\%), palate and rib malformations, kidney abnormalities, and fetal weight retardation. A combination of the three vitamins was effective in reducing VPA-induced exencephaly (23-30\%), spina bifida occulta $(60 \%)$, and palate and rib malformations (Elmazar et al., 1992; Baran et al., 2006).

Epidemiologic studies have shown that more than $90 \%$ of women using antiepileptic drugs during pregnancy deliver normal healthy babies. However, low risk but important increases in anomalieshave been determined due to intrauterine exposure of fetuses to such antiepileptic drugs as phenobarbital, diphenylhydantoin, carbamazepine, and VPA (Koch et al., 1992; Tanganelli \& Regesta, 1992).

Major fetal malformations are generally rare if human fetuses are not exposed to teratogenic drugs after organogenesis period (prior to the 36th day of the pregnancy). It was claimed that reoccurrence of FA and cures with supplementary vitamins could decrease the risk (Lammer et al.). It is also estimated that folat metabolites block glutamate formly transferase enzyme, which catalyzes transformation of tetrahydrofolate into 5-formyltetrahydrofolate by VPA. The United States Public Health Service recommends that all women of normal childbearing age should consume $0.4 \mathrm{mg}$ folic acid daily in order to decrease neural tube defects (NTDs) frequency. A randomized study by British Medical Research Council reported that NTDs formation was prevented in $72 \%$ of the pregnant women using high $(4 \mathrm{mg})$ dosage of FA in 1991 (Fleming, 2001).

The antioxidant effect of vitamin E (Vit E) protects body from free radicals and harmful effects of molecules which chemically destroy fat, protein and DNA (Deeb et al., 2000). Unsaturated fat acids of membrane phospholipids at cells can easily be oxidized and turned into peroxide derivatives spontaneously as a result of the effect of metabolites. Vit $\mathrm{E}$ is the most powerful factor to prevent or neutralize the occurrence of this situation, which is called as lipid per oxidation associated with free oxygen radicals. An important chemical feature of Vit $E$ is that it has an antioxidant effect and ability to neutralize free oxygen radicals (Metin et al., 2002). Chronic treatment with VPA decreases the antioxidant levels of Vit E. The related studies have shown that Vit $\mathrm{E}$ has a protective effect against hepatotoxicity resulting from VPA application (Deeb et al.).
The aim of this study was to investigate the potential harmful effects of VPA on sciatic nerve of fetal rats maternally exposed to VPA during pregnancy at ultrastructural level using transmission electron microscope. We also investigated the possible protective effects of FA and Vit $\mathrm{E}$ in these fetal rats.

\section{MATERIAL AND METHOD}

Animals. The study was conducted in accordance with the National Institutes of Health guidelines for the use of experimental animals. After having received approval from the ethics committee, thirty-six young virgin female Wistar-albino rats (225-275 g) and their offspring served as subjects. Rats were maintained on a $12 \mathrm{hr}$ light/dark cycle at $21 \pm 1^{\circ} \mathrm{C}$ and $50 \pm 10 \%$ humidity. Wistar-albino rats were fed with a standard pellet chow and allowed tap water ad libitum. The presence of a copulatory plug or sperm in vaginal smears the following morning was indicative of a positive mating and this day was considered gestational day 0 . The pregnant rats $(\mathrm{n}=36)$ were randomly divided into five groups $(28$ pregnant rats in treatment groups, 8 pregnant rats in control group). Each pregnant rat was put into an individual cage.

\section{Experimental protocol.}

Control group ( $\mathrm{n}=8)$ : Fetuses was only fed with standard laboratory chow and tap water.

vpa group $(n=7)$ : Once per day on days 8-10 of gestation, valproic acid (Sodium valproate, Sigma P 4543) was administered subcutaneously into a loose fold of skin on the back of leg at the dose of $400 \mathrm{mg} / \mathrm{kg}$.

vpa+fa group ( $\mathrm{n}=7)$ : Once per day on days 8-10 of gestation, valproic acid was given $400 \mu \mathrm{g} / \mathrm{kg}$ ordinarily in drinking water per day during pregnancy. In addition, from the first day of gestation, folic acid (Pteryoglutamic acid vit M, Sigma F 8798) was administered via an orogastric tube at a dose of $400 \mu / \mathrm{kg}$.

vpa+vit e group ( $n=7)$ : Once per day on days 8-10 of gestation, valproic acid was administered subcutaneously into a loose fold of skin on the back of leg at the dose of 400 $\mathrm{mg} / \mathrm{kg}$. One hour before the injection of VPA, vitamin E (aTocopherol, Sigma T-3251) was administered by gastric intubation to dams at a dose of $250 \mathrm{mg} / \mathrm{kg}$ (Vorhees, 1987).

vpa+fa+vit e group ( $n=7)$ : Once per day on days 810 of gestation, valproic acid was given $400 \mu \mathrm{g} / \mathrm{kg}$ ordinarily in drinking water per day during pregnancy. In addition, from 
the first day of gestation, folic acid (Pteryoglutamic acid vit M, Sigma F 8798) was administered via an orogastric tube at a dose of $400 \mu / \mathrm{kg}$. One hour before the injection of VPA and FA, vitamin E (a-Tocopherol, Sigma T-3251) was administered by gastric intubation to dams at a dose of 250 mg/kg (Vorhees; Deeb et al.; Berry et al., 1999; Ehlers et al., 1996; Ong et al., 1983).

Surgical procedure and Histopathological Examination. For examination of sciatic nerves, the fetuses were removed by Cesarean section on day 20 of pregnancy in the rats. Then, rats were sacrificed using ketamine $(25 \mathrm{mg} / \mathrm{kg})$ anasthesia and cervical dislocation. Sciatic nerve biopsies of the fetuses obtained were fixed in $2.5 \%$ phosphate buffered glutaraldehyde. After postification with $1 \%$ osmic acid, they were dehydrated within acetone and half-thin section of tissue samples embedded in araldite was stained with toluidin blue. Then, the thin sections were stained with uranyl nitrate-lead and evaluated under Jeol 1010 transmission electron microscope, and microphotographs were taken.

Statistical analysis. Comparison of the lengths of rat fetuses in all groups.

The relationship between all groups in terms of fetal length of the offspring rats was analyzed by One-Way Anova test. Comparison of rat fetuses in all groups showed a significant difference $(\mathrm{F}=16.35, \mathrm{P}=0.001)$ (Table I).

Table I. Comparison of lengths of rat fetuses between control and treatment groups.

\begin{tabular}{lcccc}
\hline Groups & $\mathrm{n}$ & $\mathrm{X} \mathrm{m} \mathrm{SD}$ & $\mathrm{F}$ & $\mathrm{P}$ \\
control & 29 & $2.968 \mathrm{~m} 0.422$ & & \\
vpa & 36 & $1.752 \mathrm{~m} 0.312$ & & \\
vpa+fa & 28 & $1.842 \mathrm{~m} 0.222$ & 16.35 & 0.001 \\
vpa+vit e & 31 & $1.771 \mathrm{~m} 0.469$ & & \\
vpa+fa+vit & 27 & $1.854 \mathrm{~m} 0.355$ & & \\
\hline
\end{tabular}

n: Number of fetuses.

The multiple correlation for lengths in each group was evaluated by T2 test of Tamhane. As illustrated in Table I, the values of the control group were significantly different from those of the vpa, vpa+fa, vpa+vit e and vpa+fa+vit e groups $(\mathrm{P}<0.001)$. However, there was a significant difference between the control and vpa groups. The difference was not significant between vpa and other groups $(\mathrm{P}>0.05)$.

Comparison of the body weights of rat fetuses in all groups

The relationship between all groups in terms of fetal weights of the offspring rats was analyzed by One-Way
Anova test. Comparison of rat fetuses in all groups showed a significant difference $(\mathrm{F}=22.27, \mathrm{P}=0.001)$.

The multiple correlation for weights in each group was evaluated by $\mathrm{T} 2$ test of Tamhane. As illustrated in Table II, the values of control group were significantly different from those of the vpa, vpa+fa, vpa+vit e and vpa+fa+vit e groups $(\mathrm{P}<0.001)$. However, there was a significant difference between the control and vpa groups. The difference was not significant between vpa and other groups $(\mathrm{P}>0.05)$.

Table II. Comparison of body weights of rat fetuses between control and treatment groups.

\begin{tabular}{lcccc}
\hline Groups & $\mathrm{n}$ & $\mathrm{X} \mathrm{mSD}$ & $\mathrm{F}$ & $\mathrm{P}$ \\
\hline control & 29 & $2.972 \mathrm{~m} 0.242$ & & \\
vpa & 36 & $1.442 \mathrm{~m} 0.258$ & & \\
vpa+fa & 28 & $1.698 \mathrm{~m} 0.205$ & 22.27 & 0.001 \\
vpa+vit e & 31 & $1.762 \mathrm{~m} 0.842$ & & \\
vpa+fa+vit e & 27 & $1.803 \mathrm{~m} 0.759$ & & \\
\hline
\end{tabular}

n: Number of fetuses.

\section{RESULTS}

Results of the control group. Twenty-nine fetuses were obtained from seven rats of control group. When histologically examined by a transmission electron microscopy, myelinated and unmyelinated nerve fibers of sciatic nerve were found to be normal. The axons, myelin coat, Schmidt-Lantermann clefts, Schwann cells and endoneurium were normal ultrastructural feautures in all examined control tissue specimens. In addition, unmyelinated axons were also normal (Fig. 1).

Results of the vpa group. Thirty-six fetuses were obtained from seven rats of vpa group. Examination of the samples belonging to this group showed striking ultrastructural changes affecting mainly the myelin coat. In some of the axons, degenerative changes were moderate (Fig. 2). In these areas exhibiting relatively normal structure, SchmidtLantermann clefts were observed to be extended greatly possibly representing the future focus of demyelinization. However, in most samples extensive demyelinization areas were present (Fig. 3). Detachment of myelin lamellae, invasion towards axolemma due to loss of axoplasm was evident in these samples. Regarding Schwann cell coat and endoneurium, most prominent finding was condensation of collagen fibers in extensively demyelinated samples, while moderately effected areas were relatively normal. At certain areas swelling of Schwann cells resulting in dispersion of organelles was detected. 


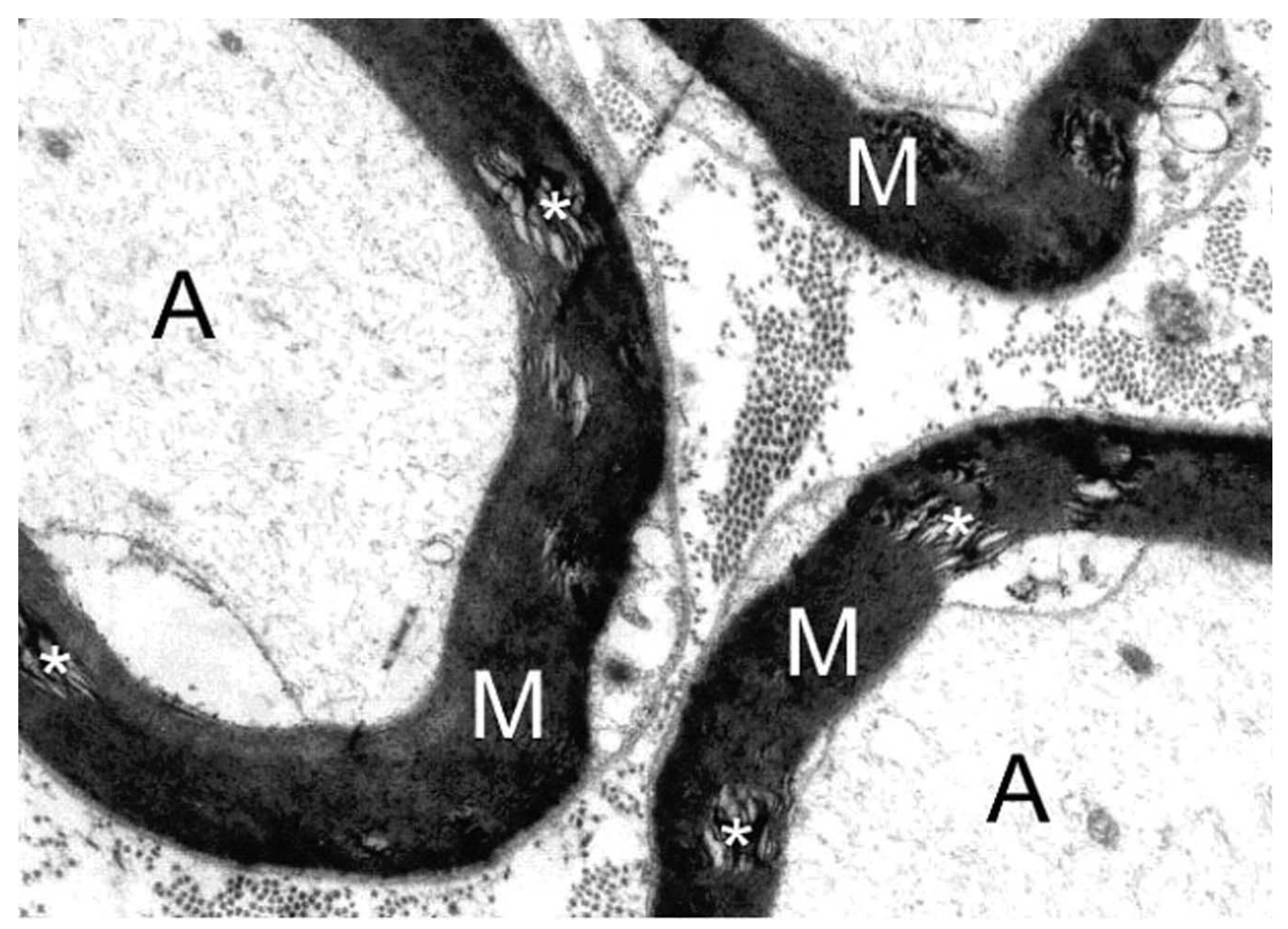

Fig. 1. Sciatic Nerve Section of Controls; axons (A) and myelin sheet (M) appear with normal ultrastructural features. Endoneurium with collagen fibers and neurilemma (Schwann cell coat) also appear normal. SchmidtLantermann clefts (*). (Uranyl acetate-lead citrate, X7000, Scale bars $=1.1 \mu \mathrm{m}$ ).

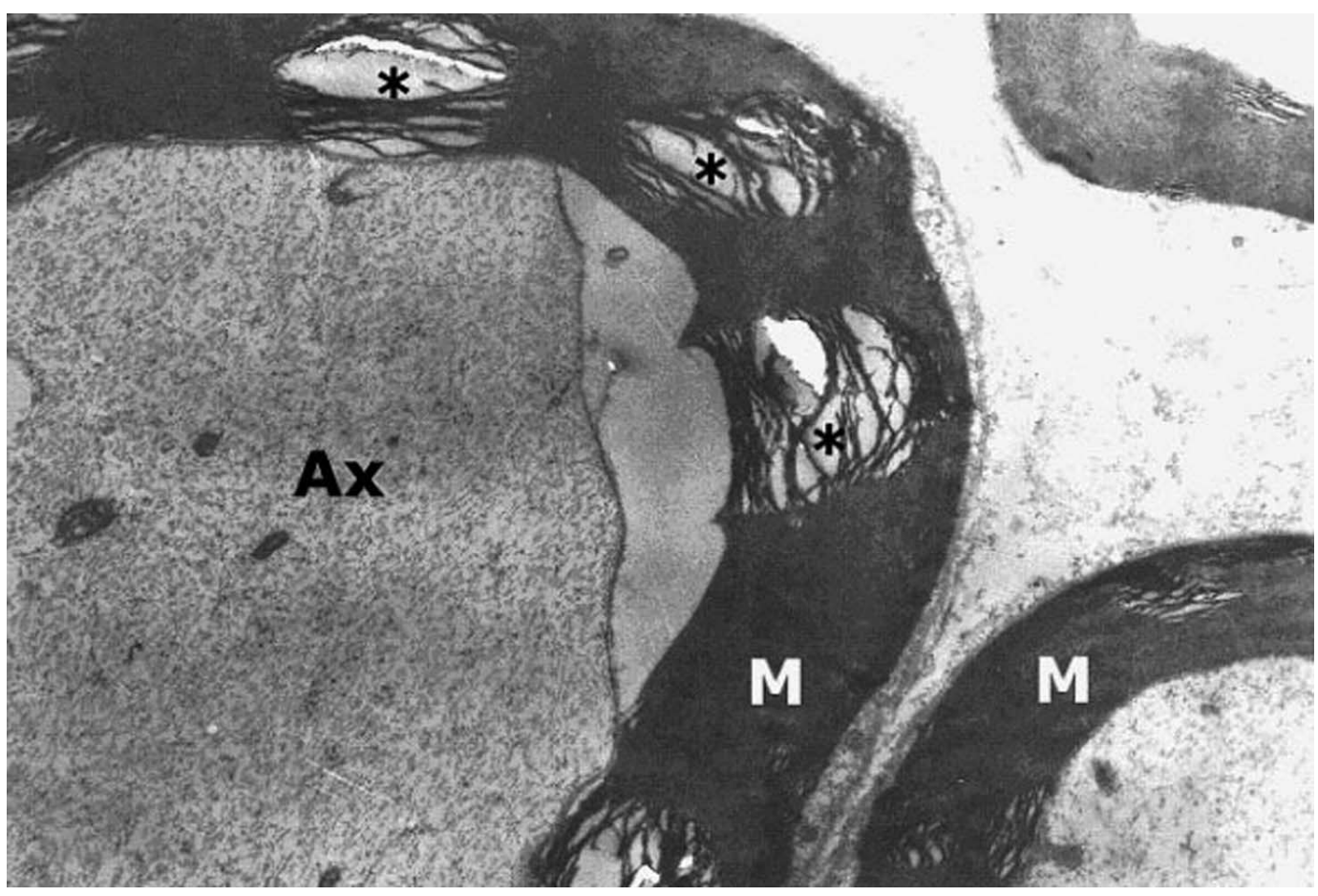

Fig. 2. Another sample of VPA Group.Detachment of myelin lamellae at Schmidt-Lanterman clefts $(*)$ are seen in detail at a higher magnification. Axons (Ax); myelin (M), (Uranyl acetate-lead citrate, X7000, Scale bars=1.1 $\mu \mathrm{m})$. 


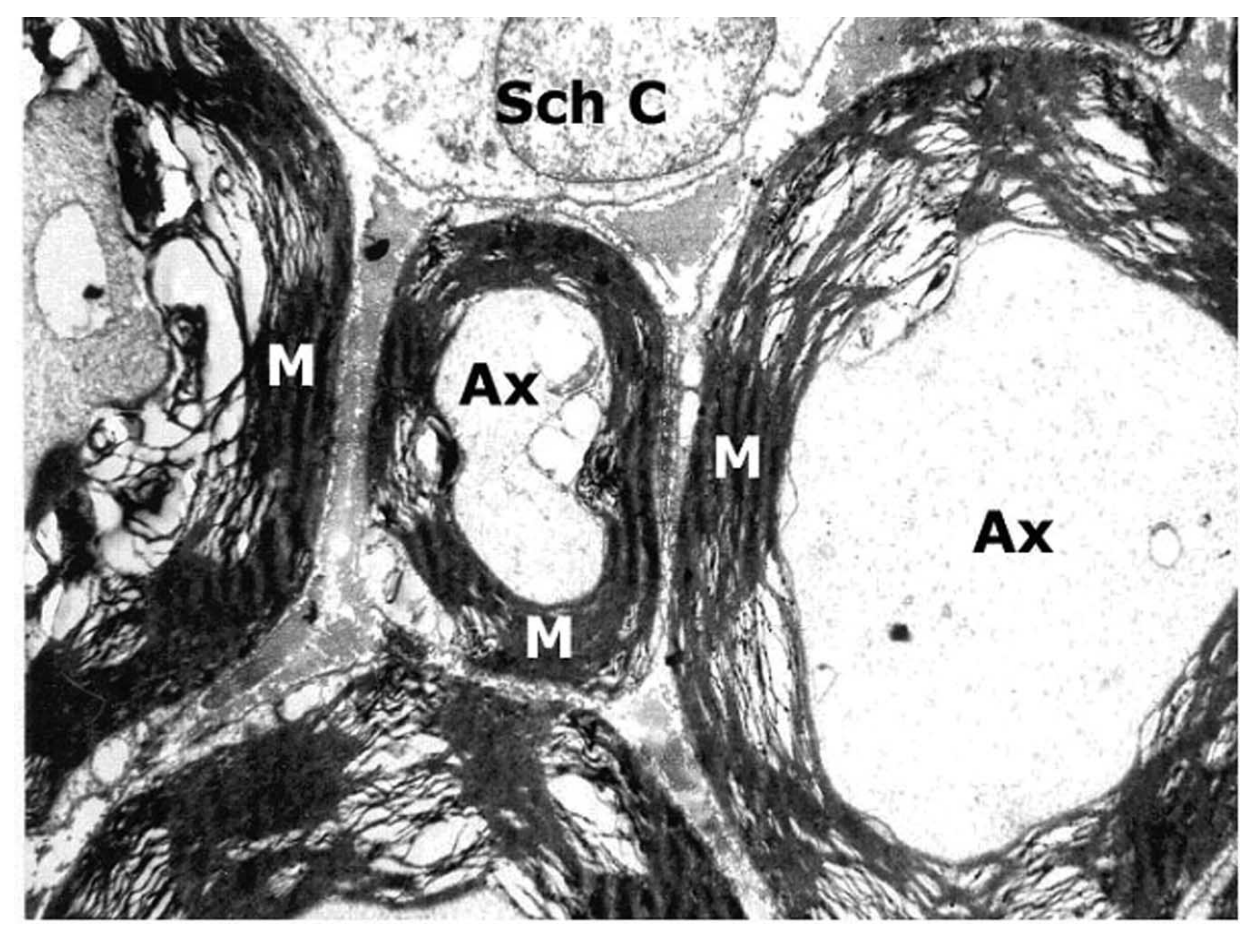

Fig. 3. Electronmicrograph of another sample from the same group. At this area demyelinization is more striking. Condensation of collagen fibers probably due to relative loss of extracellular fluid is also distinguished. Schwann cell (Sch C), Axons (Ax), Myelin (M); (Uranyl acetate-lead citrate, X7000, Scale bars $=1.1 \mu \mathrm{m})$.

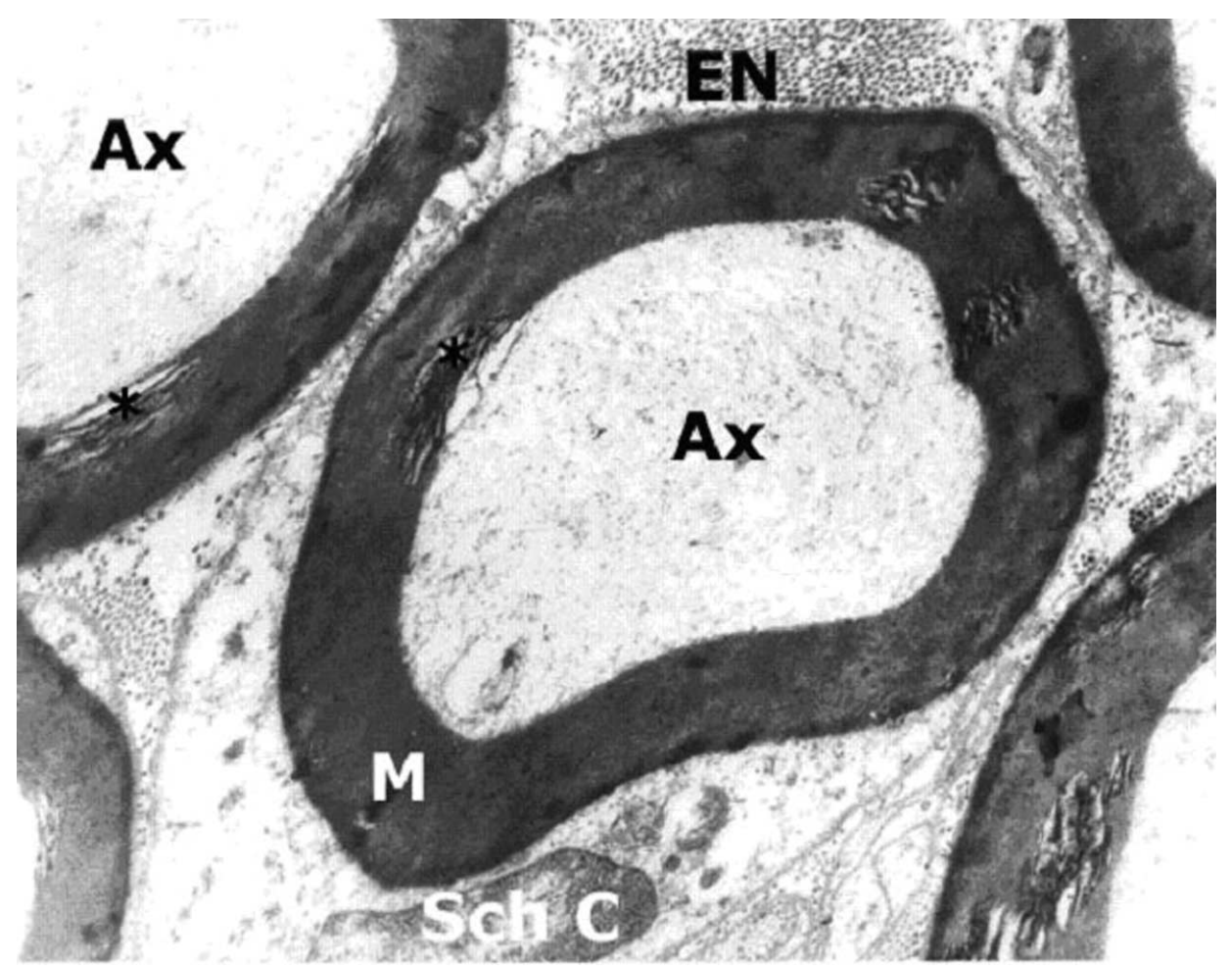

Fig. 4. Section of vpa+fa group. Schwann cell (Sch C) and adjacent cytoplasmic compartment (neurilemma) and endoneurium (EN) appear normal. Myelin sheet also appear intact though lamellae are not distinguished clearly. Axons (Ax), Myelin (M), (Uranyl acetate-lead citrate, X7000, Scale bars $=1.1 \mu \mathrm{m})$. 


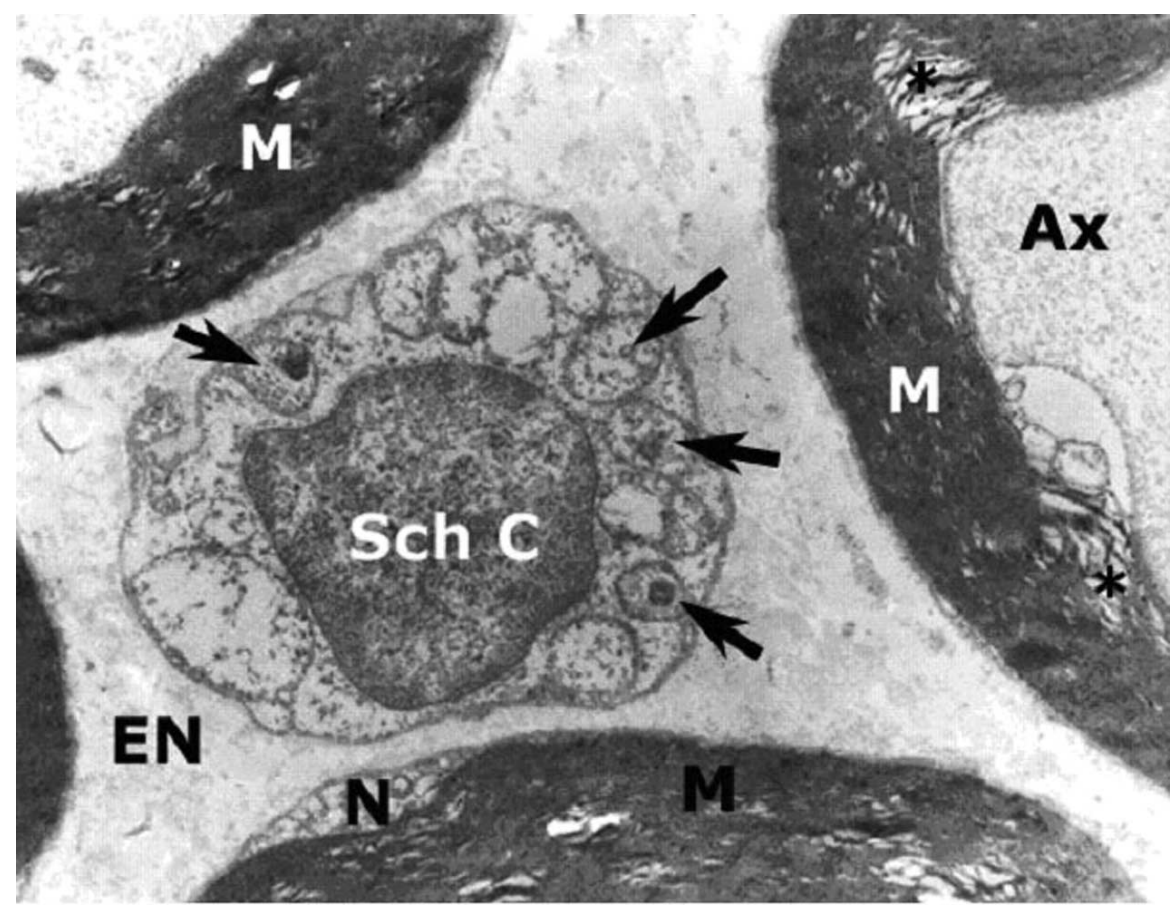

Fig. 5. Section of a sample from vpa+vit e group was similar as in vpa+fa group, most components appear normal. Some of the unmyelinated axons (arrows) contain an electron dense material of unknown significance. Schwann cell (Sch C), Axons (Ax), Myelin (M), endoneurium (EN), (Uranyl acetate-lead citrate, X7000, Scale bars=0.6 $\mu \mathrm{m}$ ).

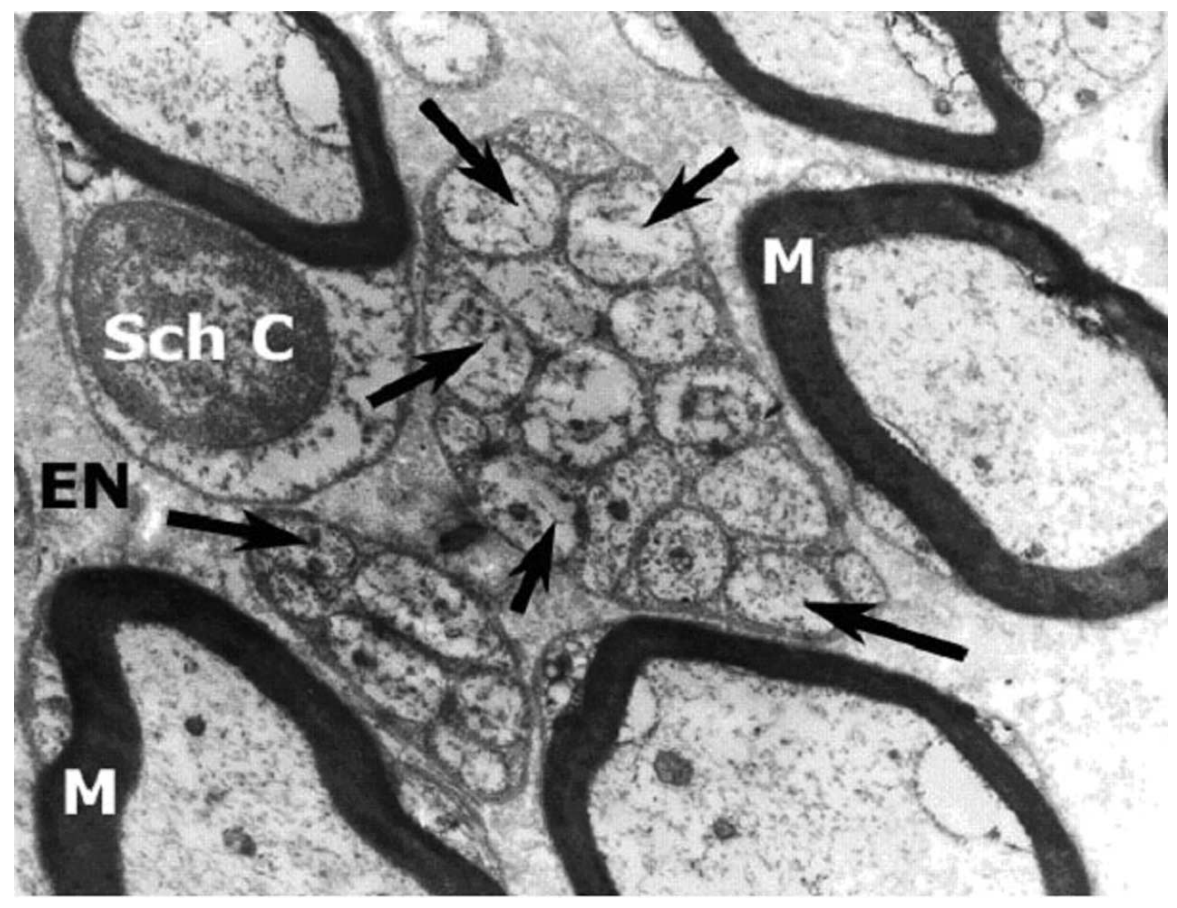

Fig. 6. Section of vpa+fa+vit e Group. Pathological changes observed in vpa group Mostly reverted to normal ultrastructural characteristics in all compartments. Myelin sheet $(\mathrm{M})$ apeears normal without any demyelinizating areas, though myelin lamellae and Schmidt-Lantermann clefts are not clearly outlined. Unmyelinated nerve fibers (arrows), Schwann cells (Sch C) and endoneurium (EN) also exhibit normal structure (Uranyl acetate-lead citrate, X7000, Scale bars $=0.6 \mu \mathrm{m})$.
Results of the vpa+fa group. Twenty-eight fetuses were obtained from seven rats of vpa+fa group. Sections belonging to this group showed relatively normal ultrastructure when compared to VPA group. Demyelinization was observed to be greatly reduced, Schwann cells and endoneurial compartment appeared normal (Fig. 4).

\section{Results of the vpa+vit e group}

Thirty-one fetuses were obtained from seven rats of vpa+vit e group. Similarly, findings in vpa+fa group were also determined in vpa+vit e group. Degenerative changes in myelin sheet, Schwann cells and endoneurium was minimal and the nerve appeared to be keeping its normal ultrastructural features. In some unmyelinated fibers, electron dense condensations of unknown signifance were observed (Fig. 5).

\section{Results of the vpa+fa+vit e group}

Twenty-seven fetuses were obtained from seven rats of vpa+vit e group. Findings of this group was almost identical with those of the control group. Axons, myelin sheet, Schwann cell coat and endoneurium all appeared having normal ultrastructural characteristics (Fig. 6).

In all samples examined a common unusual finding was partial detachment of axolemma and myelin sheet.

\section{DISCUSSION}

VPA is a widely used antiepileptic drug since the 1970s., 
leading to skeleton defects, fetal growth retardation, neural tube defects and in-uterus death (Elmazar \& Nau, 1995; Sato et al., 1995). It is routinely used to treat epilepsy (Dalessio, 1985). However, valproic acid is also known to cross the placenta and to cause a wide spectrum of congenital anomalies, including craniofacial and skeletal defects (Lammer et al.; Dansky and Finnell, 1991). The teratogenic effect mechanism of VPA has not been precisely clarified. The proposed hypothesis claims that VPA is an important risk factor, inducing congenital malformations, and lack of folat results in teratogenicity (Engelsen et al., 1983). Although VPA induces exencephaly in experimental animal embryos, its pathogenic mechanism is not known reported that, in the 8th day of gestation, VPA application causes growth retardation in fetuses (Deeb et al.; Padmanabhan \& Shafiullah, 2003). Embryo toxicity of VPA has been previously shown by clinical and experimental findings (Elmazar et al.). In our study, growth retardation that exhibits similar findings to pregnant rat fetuses was macroscopically observed. In sciatic nerve, prominent demyelinization in the nerve fibers was detected in the present study. These findings are, at least partly, compatible with their clinical findings (Elmazar et al.).

Numerous studies point towards the role of oxygen derived free radicals in the pathogenesis of neural tube defects (Deeb et al.; Robert \& Guibaud, 1982). Exposure of rat embryos to high concentration of oxygen during early neurulation (days 9-10) significantly increases the incidence of neural tube defects and is dependent on the capacity of the antioxidant system to combat oxygen derived free radicals (Ishibashi et al., 1997). Furthermore, treatment of patients with VPA along with other antiepileptic drugs has been shown to reduce blood Vit E levels (Tamai et al., 1988). The occurrence mechanism of spina bifida by VPA is not completely known, but the first related hypothesis claims that the inhibition of FA mechanism and lack of FA is the primary mechanism responsible for teratogenicity (Carl, 1986; Dansky et al., 1992). FA acts as a coenzyme in reduction, DNA synthesis, protein metabolism and methyl donor reactions (Bailey \& Gregory, 1999; Steegers-Theunissen, 1995). The lack of FA can cause DNA hypometylation and DNA fracture, abnormal gene production (James et al., 1999; Pogribny et al., 1997; Qu et al., 1999). They claim that FA antagonists (trimethoprim, methotrexate, oral contraceptives) could lead to some birth defects at women supports this suggestion (Hernandez-Diaz et al., 2000). In an experimental study, it has been reported that addition of FA to food of rats decreases NTDs incidence, induced by VPA (Wegner \& Nau, 1991).
The second hypothesis is that free radicals have a significant role in cytotoxicity, hepatotoxicity and pathogenesis of teratogenite, induced by VPA (Graf et al., 1998; Jurima-Romet et al., 1996). It is known that FA reduction leads to decrease in body antioxidant defense and increase in production of free radicals. In addition, it also induces oxidative stress (Durand et al., 1997).

In this study, examination of samples belonging to vpa+fa group revealed a beneficial effect of folic acid to prevent the demyelinization caused by VPA significantly. Our findings were similar to those reported in the previous studies (Berry et al.).

Although Vit E alone had no significant effect on fetal survival and growth, it significantly attenuated VPA induced fetal toxicity and malformations. These findings are consistent with earlier clinical and experimental reports, showing embryo toxicity of VPA (Elmazar et al.; Robert \& Guibaud). Decreases Vit E level in blood have been described in VPA and other antiepileptic drug users (Tamai et al.). Antioxidants containing aTocopherol and N,N'-diphenyl-p-phenylenediamine have been shown to affect protection against hepatotoxicity induced by VPA (Buchi et al., 1984). It is also reported that they have useful effects on fetal toxicity, which is induced by drugs or illness (Kelly et $a l ., 1984)$. In addition, Vit E reduces fetal malformation in diabetic animals (Siman \& Eriksson, 1997). Continuous VPA treatment decreases levels of antioxidants such as Vit E and glutathione peroxidase, resulting in oxidative stress (Kotch et al., 1995; Tamai et al.). In our study, Vit E also detected to be preventing the demyelinization produced by maternally administered VPA. Both FA and Vit E had beneficial effects to a certain degree, exhibiting similar findings ultrastructurally. However administration of both agents together found out to be more effective when compared to both agents administered alone. Our findings of the present study suggest that administration of FA and Vit E combination will be more beneficial to prevent the harmful effects caused by VPA.

In conclusion, our findings show that the usage of VPA during gestational period might clinically create risk, but this risk can be reduced by FA administration. In addition, Vit $\mathrm{E}$ was found to be similar protective of FA. This effect of Vit E may be due to its antioxidant property. We consider that administration of FA together with Vit E in case of maternal VPA administration during pregnancy may reduce neural degenerative changes seen in sciatic nerve. 
ALUCLU, M. U.; TUNCER, M. C.; GUZEL, A.; ALUCLU, M. A. \& AKKUS, M. Efectos del ácido valproico sobre el nervio ciático de fetos de ratas y efectos de protección del ácido fólico y vitamina E. Int. J. Morphol., 27(2):285-294, 2009.

RESUMEN: El objetivo fue investigar los posibles efectos perjudiciales del ácido valproico (AVP) materno sobre el nervio ciático en fetos y los efectos protectores de la vitamina $\mathrm{E}$ (Vit E) y ácido fólico (AF) en fetos de ratas. Se administraron a ratas ácido valproico $(400 \mathrm{mg} / \mathrm{kg})$, ácido fólico $(400 \mathrm{mg} / \mathrm{kg})$ y vitamina $\mathrm{E}(250 \mathrm{mg} / \mathrm{kg})$ en cada uno de los días de gestación 8-10. Todos los fetos fueron recogidos a los 20 días de gestación. Finas secciones de biopsias obtenidas de los nervios ciáticos de fetos fueron teñidos con acetato de uranilo y examinados bajo microscopio electrónico de transmisión. Los fetos (n: 36) fueron divididos en cinco grupos: control, avp, avp+af, avp+vit e y avp+fa+vit e. En cada grupo, se realizaron los procedimiento farmacológicos, quirúrgicos y los métodos histológicos. Los pesos y longitudes de los fetos de cada grupo fueron comparados y analizados usando la prueba One-Way Anova. La administración de dosis únicas de ácido valproico $(400 \mathrm{mg} / \mathrm{kg}$ ) resultó en la pérdida del peso la longitud entre el control y el grupo apv. Sin embargo, las diferencias en la longitud y el peso entre los otros grupos no fueron significativas. Los hallazgos histopatológicos del grupo control fueron normales. En el grupo avp, se mostró especialmente cambios degenerativos en la mielina que envuelve al nervio periféricamente. Además, predominatemente se encontró en las muestras de este grupo fibras colágenas condensadas y zonas ampliamente desmielinizadas, mientras que las zonas moderadamente afectadas eran relativamente normales. Ambos grupos avp+fa y avp+vit e exhibieron cambios ultraestructurales similares, lo que supone un mínimo o moderado cambio degenerativo. El grupo avp+fa+vit e tuvo casi una estructura normal. La administración de dosis únicas de ácido valproico $(400 \mathrm{mg} / \mathrm{kg})$ produjo un efecto sobre el deterioro del nervio ciático a nivel ultraestructural. La administración de la AF y vitamina E tienen un efecto protector, en cierta medida, para evitar la cambios degenerativos. La combinación de AF y vitamina E, junto a la ulterior administración de AVP tienen un efecto protector más potente. El objetivo del presente estudio fue analizar los cambios histopatológicos que pueden ocurrir en un modelo experimental de alto riesgo después de la administración de ácido valproico. Además, fueron evaluadas las funciones de protección de la administración de ácido fólico y la vitamina E.

PALABRAS CLAVE: Ácido valproico; Nervio ciático; Ácido fólico; Vitamina E; Rata.

\section{REFERENCES}

Annegers, J. F.; Baumgartner, K. B.; Hauser, W. A. \& Kurland, L. T. Epilepsy, antiepileptic drugs, and the risk of spontaneous abortion. Epilepsia, 29:451-8, 1988.

Bailey, L. B. \& Gregory, J. F. Folate metabolism and requirements. J. Nutr., 129:779-82, 1999.

Baran, Ö.; Nergiz, Y. \& Tuncer, M. C. The effects of valproic acid, vitamin $\mathrm{E}$ and folic acid on ribs of rat fetuses in the prenatal period. Ann. Anat., 188:117-25, 2006.

Berry, R. J.; Li, Z.; Erickson, J. D.; Li, S.; Moore, C. A.; Wang, H.; Mulinare, J.; Zhao, P.; Wong, L. Y.; Gindler, J.; Hong, S. X. \& Correa, A. Prevention of neural-tube defects with folic acid in China. China-U.S. Collaborative Project for Neural Tube Defect Prevention. N. Engl. J. Med., 11:1485-90, 1999.

Biernacki, B.; Wlodarczyk, B. \& Minta, M. Effect of sodium valproate on rat embryo development in vitro. Bull. Vet. Inst. Pulawy., 44:201-5, 2000.

Buchi, K. N.; Gray, P. D.; Rollins, D. E. \& Tolman, K. G. Protection against sodium valproate injury in isolated hepatocytes by alpha-tocopherol and N,N'-diphenyl-pphenylenediamine. J. Clin. Pharmacol., 24:148-54, 1984.
Carl, G. F. Effect of chronic valproate treatment on folatedependent methyl biosynthesis in the rat. Neurochem. Res., 11:671-85, 1986.

Ceylan, S.; Duru, S. \& Ceylan, S. Valproic acid sodiuminduced spina bifida occulta in the rat. Neurosurg. Rev., 24:31-4, 2001.

Dalessio, D. J. Current concepts: Seizure disorders and pregnancy. New. Engl. J. Med., 312:559-63, 1985.

Dansky, L. V. \& Finnell, R. H. Parental epilepsy, anticonvulsant drugs, and reproductive outcome: epidemiologic and experimental findings spanning three decades; 2: Human studies. Reprod. Toxicol., 5:301-35, 1991.

Dansky, L.V.; Rosenblatt, D. S. \& Andermann, E. Mechanisms of teratogenesis: folic acid and antiepileptic therapy. Neurology, 42:32-42, 1992.

Deeb, S. A.; Moutaery, K. A.; Arshaduddin, M. \& Tariq, M. Vitamin E decreases valproic acid induced neural tube defects in mice. Neurosci. Lett., 292:179-82, 2000.

Dickinson, R. G.; Harland, R. C.; Ilias, A. M.; Rodgers, R. M.; Kaufman, S. N.; Lynn, R. K. \& Gerber, N. 
Disposition of valproic acid in the rat: dose-dependent metabolism, distribution, enterohepatic recirculation and choleretic effect. J. Pharmacol. Exp. Ther, 211:583-95, 1979.

Durand, P.; Prost, M. \& Blache, D. Folic acid deficiency enhances oral contraceptive induced platelet hyperactivity. Arterioscler. Thromb. Vasc. Biol., 17:1939-46, 1997.

Ehlers, K.; Elmazar, M. M. \& Nau, H. Methionine reduces the valproic acid-induced spina bifida rate in mice without altering valproic acid kinetics. J. Nutr., 126:6775, 1996.

Elmazar, M. M.; Thiel, R. \& Nau, H. Effect of supplementation with folinic acid, vitamin B6 and vitamin B12 on valproic acid induced teratogenesis in mice. Fundam. Appl. Toxicol., 18:389-94, 1992.

Elmazar, M. M. \& Nau, H. Ethanol potentiates valproic acidinduced neural tube defects (NTDs) in mice due to toxicokinetic interactions. Reprod. Toxicol., 9:427-33, 1995.

Engelsen, B.; Stranjord, R.; Gjerde, I. O.; Markestadt, T.; Ulstein, M. \& Evjen, O. K. Folate concentrations in woman on antiepileptic drug (AED) therapy. Acta Neurol. Scand., 69:83-4, 1983.

Fleming, A. The role of folate in the prevention of neural tube defects: human and animal studies. Nutr. Rev., 59:1320, 2001.

Graf, W. D.; Oleinik, O. E.; Glauser, T. A.; Maertens, P.; Eder, D. N. \& Rippenger, G. E. Altered antioxidant enzyme activities in children with a serious adverse experience related to valproic acid therapy. Neuropediatrics, 29:195-201, 1998.

Hansen, D. K. \& Grafton, T. F. Lack of attenuation of valproic acid-induced effects by folinic acid in rat embryos in vitro. Teratology, 43:575-82, 1991.

Hernandez-Diaz, S.; Werler, M. M.; Walker, A. M. \& Mitchell, A. A. Folic acid antagonists during pregnancy and the risk of birth defects. N. Engl. J. Med., 30:1608$14,2000$.

Ishibashi, M.; Akazawa, S.; Sakamaki, H.; Matsumoto, K.; Yamasaki, H.; Yamaguchi, Y.; Goto, S.; Urata, Y.; Kondo, T. \& Nagataki, S. Oxygen induced embryopathy and the significance of glutathione dependent antioxidant system in the rat embryo during early organogenesis. Free. Radic. Biol. Med., 22:447-54, 1997.

James, S. J.; Pogribna, M.; Pogribny, I. P.; Melnyk, S.; Hine, R. J.; Gibson, J. B.; Yi, P.; Tafoya, D. L.; Swenson, D. H.; Wilson, V. L. \& Gaylor, D. W. Abnormal folate metabolism and mutation in the methylenetetrahydrofolate reductase gene may be maternal risk factors for Down syndrome. Am. J. Clin. Nutr, 70:495-501, 1999.

Jurima-Romet, M.; Abbott, F. S.; Tang, W.; Huang, H. S. \& Whitehouse, L. W. Cytotoxicity of unsaturated metabolites of valproic acid and protection by vitamins $\mathrm{C}$ and $\mathrm{E}$ in glutathione depleted rat hepatocytes. Toxicology, 112:69-85, 1996.

Kelly, T. E.; Edwards, P.; Rein, M.; Miller, J. Q. \& Dreifuss, F. E. Teratogenicity of anticonvulsant drugs. II: A prospective study. Am. J. Med. Genet., 19:435-43, 1984.

Koch, S.; Losche, G.; Jager-Roman, E.; Jakob, S.; Rating, D.; Deichl, A. \& Helge, H. Major and minor birth malformations and antiepileptic drugs. Neurology, 42:838, 1992.

Kotch, L. E.; Chen, S. Y. \& Sulik, K. K. Ethanol-induced teratogenesis: free radical damage as a possible mechanism. Teratology, 52:128-36, 1995.

Lammer, E. J.; Sever, L. E. \& Oakley, G. P. Teratogen update: valproic acid. Teratology, 35:465-73, 1987.

Metin, G.; Atukeren, P.; Gumustas, M. K. \& Belce, A. The Effect of Vitamin E Treatment on Oxidative Stress Generated in Trained Rats. Tohoku J. Exp. Med., 198:4753, 2002.

Nau, H.; Hauck, R. S. \& Ehlers, K. Valproic acid-induced neural tube defects in mouse and human: aspects of chirality, alternative drug development, pharmacokinetics and possible mechanisms. Pharmacol. Toxicol., 69:310-21, 1991.

Ong, L. L.; Schardein, J. L.; Petrere, J. A.; Sakowski, R.; Jordan, H.; Humphrey, R. R.; Fitzgerald, J. E. \& de la Iglesia, F. A. Teratogenesis of calcium valproate in rats. Fund. Appl. Toxicol., 3:121-6, 1983.

Padmanabhan, R. \& Shafiullah, M. M. Amelioration of sodium valproate-induced neural tube defects in mouse fetuses by maternal folic acid supplementation during gestation. Congenit. Anom. (Kyoto), 43:29-40, 2003. 
Pogribny, I. P.; Muskhelishvili, L.; Miller, B. J. \& James, S. $\mathrm{J}$. Presence and consequence of uracil in preneoplastic DNA from folate/methyl-deficient rats. Carcinogenesis, 18:2071-6, 1997.

Qu, G. Z.; Grundy, P. E.; Narayan, A. \& Ehrlich, M. Frequent hypomethylation in Wilms tumors of pericentromeric DNA in chromosomes 1 and 16. Cancer Genet. Cytogenet., 109:34-9, 1999.

Robert, E. \& Guibaud, P. Maternal valproic acid and congenital neural tube defects. Lancet, 2:937, 1982.

Sato, M.; Shirota, M. \& Nagao, T. Pantothenic acid decreases valproic acid-induced neural tube defects in mice (I). Teratology, 52:143-8, 1995.

Siman, C. M. \& Eriksson, U. J. Vitamin E decreases the occurrence of malformations in the offspring of diabetic rats. Diabetes, 46:1054-61, 1997.

Steegers-Theunissen, R. P. Folate metabolism and neural tube defects: a review. Eur. J. Obstet. Gynecol. Reprod. Biol., 61:39-48, 1995.

Tamai, H.; Wakamiya, E.; Mino, M. \& Iwakoshi, M. Alphatocopherol and fatty acid levels in red blood cells in patients treated with antiepileptic drugs. J. Nutr. Sci. Vitaminol., 34:627-31, 1988.
Tanganelli, P. \& Regesta, G. Epilepsy, pregnancy, and major birth anomalies: an Italian prospective, controlled study. Neurology, 42:89-93 1992.

Vorhees, C. V. Teratogenicity and developmental toxicology of valproic acid in rats. Teratology, 35:195-202, 1987.

Wegner, C. \& Nau, H. Diurnal variation of folate concentrations in mouse embryo and plasma. The protective effect of folinic acid on valproic acid-induced teratogenicity is time dependent. Reprod. Toxicol., 5:46571, 1991.

\section{Correspondence to:}

Dr. Mehmet Cudi Tuncer

Department of Anatomy

Faculty of Medicine

University of Dicle

Diyarbakır

TURKEY

Tel: +90 4122488001

Fax: +90 4122242083

E-mail: cudi@dicle.edu.tr

Received: 12-11-2008

Accepted: 09-12-2009 